\title{
PART 4. \\ EDUCATIONAL, CULTURAL AND SCIENTIFIC ACTIVITY OF METROPOLITAN ANDREY SHEPTYTSKY
}

At the end of the 19th century, under Metropolitan Sembratovych, the church was in a real crisis. Metropolitan Andrey Sheptytsky tried to overcome this crisis, to bring the church to the level of new tasks, make it a fact not only of national revival, but also of national state formation, to make it as a completely national, Ukrainian religious association. A. Sheptytsky clearly stated his life credo in a pastoral letter "To the Ukrainian intelligentsia": "In every work and in every word... I seek only the good of the people, for whom I feel like my heavy and holy duties. These responsibilities are imposed on me not only by my position as Metropolitan, but also by the solemn swear, made on the day of joining the monastery, that I will, according to my strength, work for the Ukrainian community, because I have a strong conviction, that puts me in the ranks of patriots, of which I wanted to be the best" ${ }^{\text {"182 }}$.

Metropolitan's devotion to his swear and to his vocation was carried through the years and never receded from its foundations, though his life's journey was difficult. Therefore, bearing in mind his own ascetic activities, he rightly noted in a sincere "Word to Ukrainian Youth": "And it is easier to shed blood in one minute of enthusiasm, than to hardly fulfill the duties through long years and move the heat of the day, and the heat of the sun, and the malice of the people, and the hatred of the enemies, and the lack of our people's confidence, and the lack of help from the closest one's, and in the midst of such labor, do your task until the end, without waiting for the laurels before the victory, nor the reward before the merit!"183

The very appearance of A. Sheptytsky in the bosom of the Greek Catholic Church was sensational, and the sacrifice of his step - undoubted (title, position, career, estate - to a persecuted "khlop church"). The most impressive was not a fact that he became a Greek Catholic from a Roman

${ }^{182}$ Митрополит Шептицький Андрей. Твори. Т. 2. Торонто, 1965. С. 190.

${ }^{183}$ Гайковський М. Нація і держава в богословській спадщині митрополита Андрея Шептицького. Науковий збірник УВУ. Матеріали конференції «Народ, нація, держава і українське питання у європейському вимірі» (Львів, травень 1993). Мюнхен - Львів, 1995. C. 195. 
Catholic, but how he became a Ukrainian from a Pole ${ }^{184}$. This was an important factor in raising the national consciousness of the Galician people and the reason for continued hostility towards him from the Polish authorities and the community.

It should be noted, however, that both Ukrainian politicians and the national press met him, to put it mildly, without applause. Brilliant abilities and education, rapid advancement in the Greek Catholic ecclesiastical hierarchy caused to first treat him as a Polish agent. Speeches and actions of Sheptytsky in defense of the Ukrainian movement seemed to dispel doubts about the sincerity of his religious and national approach. But when he, feeling moral necessity, took on some unpopular position, the critics were not afraid to say that his true Polish aristocratic colors were manifested in him, and compared him to Valenrod of A. Mickiewicz.

Another reason for this hostile attitude was a comparatively tolerant treatment of Moscophiles by A. Sheptytsky. Before coming to the Metropolitan throne, he was a bishop of Stanislav for one year. At that time, he did not yet orient himself in public life and cooperated with the Moscophiles, who were the majority among the clergy of the Stanislav diocese. At the same time, he understood that the Moscophiles' tendencies were related to the serious and real problems of religious and national identification. As I. Khymka notes, "Greek Catholics had an Orthodox face, Roman Catholic citizenship and... an enlightened Austrian soul. All these elements did not reproduce the new religious synthesis" $" 185$. It was very difficult to choose your own right path in such circumstances. That is why A. Sheptytsky stated that in solving any national or religious issues, it is not enough to be guided by feelings, but, above all, by the mind. However, even much later, in 1943, he had to state bitterly: "Such thunderous manifestations as Moscophiles in many reviews are almost a mystery to us. I have never had the opportunity to re-read the notorious research about this national ulcer, and I do not even remember whether there are at all any brief,

${ }^{184}$ This Ukrainian nature of a future Metropolitan is described well by S. Herman in his novel: “- Sir made a mistake, Mr. Sheptytsky, - secretary of the dean's office of the law faculty of Jagiellonian University, a small, thin man in silver pence, gave Roman a questionnaire, submitted a minute ago. - A mistake? What's the mistake? - Roman asked. - Here, in the column "nationality", Mr. wrote "Rusyn". For Count Sheptytsky, you agree, it sounds like ... uh ... not quite, to say, okay... Roman took the questionnaire, re-read it and, without making any corrections, gave it to the secretary. - Everything is written correctly here. - Right? You say everything is spelled correctly? Well ... I wish my lord, Count Sheptytsky, all successes, - said the secretary, and his pence flashed with a cold glare" (Герман C. Via Романа. Життя митрополита А. Шептицького. К.: Ярославів вал, 2019. С. 9).

${ }_{185}$ Химка І. Греко-католицька церква і національне відродження у Галичині 17721918. Ковчег: Збірник статей з церковної історії. Число 1. Львів, 1993. С. 77-78. 
but deeply considered, observations of this ulcer in our literature. When the struggle between these two parties [the "Moscophiles" and the "Ukrainephiles" - Aut.] was most severe in our region, there were no serious judgments from both sides about the mutual relations or intentions of the two parties. They mutually quarreled, they accused each other of treason, and no one came up with a question to ask what causes them and their opponents to think as they think ${ }^{186}$.

Such a moderate attitude of A. Sheptytsky caused dissatisfaction in the certain circles of the Ukrainian intelligentsia not only during the beginning of his activity, but also during his stay at the Metropolitan's throne. The open conflict of A. Sheptytsky with the editor of the newspaper "Dilo" L. Tsehelsky in 1908 is a good example of this. ${ }^{187}$

New Metropolitan was welcomed with some caution in the church community. The reason for this was his dissimilarity to his predecessors. Prominent Ukrainian writers I. Franko and M. Pavlyk, who often visited A. Sheptytsky with scientific affairs, were surprised by the way of life of the Earl-Metropolitan. He lived as an ascetic: a small room, alone in a woolen black monk's cowl, belted by an ordinary black belt, with prear beads on his belt or in his hands, the most modest dish, the doors of his wards at St. George's Mountain are always open to all around him and to everyone else, even to the enemies.

However, not only the extraordinary personal modesty of A. Sheptytsky caused the general astonishment and attention to his personality, but also another extraordinary circumstance at that time. Even in the Stanislav period of his life, he addressed a pastoral message to the believers of the Kosovan deanery - "To my beloved Hutsuls" 188 . In its content this message is not exceptional: A. Sheptytsky later will return repeatedly to the moral problems raised here. But the form of the message is a kind of a manifesto - it is written in the Hutsul dialect. To understand the significance of this act, it should be mentioned that at that time even a common orthography did not

\footnotetext{
${ }^{186}$ Шептицький Андрей. Пастирські послання 1939-1944 рр. Т. 3. Львів: Видавництво «АРTOC», 2010. С. 570.

187 Левіцький К. Історія політичної думки галицьких українців, 1848-1914. Жовква, 1927. C. 494-495. This conflict did not prevent Lonhyn Tsehelsky from praising the Metropolitan's longstanding actions: "Metropolitan Sheptytsky... extended his authority to all Ukraine and to Ukrainian emigration in Europe and overseas. And since Orthodox Ukrainians do not have any prominent ruler, Metropolitan Kyr Andrey became the spiritual leader of the entire Ukrainian people, and Orthodox Ukrainians bow to His respect and recognize His authority" (Цегельський Л. Митрополит Андрій Шептицький. Короткий життєпис і огляд його церковно-народної діяльності. Львів: Видавництво отців василіан «МІСІОНЕР», 1995. C. 20-21.)

${ }^{188}$ Шептицький А. Послання любови. Брустури: Дискурсус, 2015. С. 104-139.
} 
exist and it was used an extremely complex mix of Church Slavonic language with Ukrainian. Although A. Sheptytsky never used the dialect again, all his further messages were written in a language accessible to the people, clearly and understandable, in Ukrainian. I. Franko paid a special attention to this side of his activity: "...Since his coming to the bishopric, A. Sheptytsky began to accustom us to a different tone, other forms... Instead of the moldy pseudo-church language, a discerning mishmash of Church Slavonic vocabulary with modern morphology, which was used by his predecessors, he writes letters in purely Galician-Rus vernacular, and sometimes, for example, in a strong message to the Hutsuls, he is not ashamed even of speaking a dialect - an impossible matter in the speech of our dignitaries.

He does not speak as his predecessors, highly, authoritative, hypocritical, as if having a static tone, does not walk on the walkways and does not 'proclaim', but speaks simply as equal to equal, as a man to people, advises, mentions and sometimes flames without being afraid to use a vigorous word when situation requires it" ${ }^{\prime 189}$.

Despite such a biased attitude, Metropolitan Andrey's activities in the social, political and cultural spheres, his courage in the name of the nation and religion won him recognition in Ukrainian society, the respect and commitment of recent opponents.

Sheptytsky's cultural and educational activity was aimed at raising the morale and spirituality of the people to the level at which there appeared a conscious and mass readiness for practical work in the matter of national state building. A. Sheptytsky was engaged in extensive philanthropist activities, he provided material assistance to individual artists, to talented youth, conducted pedagogical work at schools, sports and educational societies ("Prosvita", "Native School", "Plast"), maintained newspapers and magazines, organized mass events with the obligatory combination of the two principles - national and religious. "The Church of Christ", Metropolitan stated, "is always far from resisting the development of culture, the arts and sciences; on the contrary, it helps and powerfully develops it.

189 Франко I. Соціальна акція, соціальне питання і соціалізм // Франко І. Зібрання творів у 50 тт. Т. 45. К., 1986. С. 378.; In the deep conviction of J. Hrytsak, Sheptytsky "treated his flock with sincere sympathy... developing the mentality of the Ruthenians out of the ritual practices of the church, he headed...” (Грицак Я. Пророк у своїй вітчизні. Франко та його спільнота (1856-1886). К.: Критика, 2006. С. 41); For more on I. Franko's attitude to Metropolitan's figure, see.: Будівничий української державності: Хрестоматія політологічних статей Івана Франка / Упоряд. Д. Павличко. К.: Видавничий дім «КиєвоМогилянська академія», 2006. С. 29, 30, 336, 498-511, 513-515, 519-521. 
The church neither lightens nor disrupts those good signs of culture that serve man..." 190 .

Metropolitan looked at the Galician people through the eyes of a politician. He understood that in order to rise to a level of statehood, the Galicians needed knowledge and printed editions. Sheptytsky generously financed printing houses, "Biblos", etc., he founded a Ukrainian publishing house in Zhovkva in Basiliyan Monastery and started the magazines "Missionary", "Our Friend". In 1930, Bishop founded the Ukrainian Catholic Union, which published the weekly "Meta" and the literary and scientific journal "Dzvony".

Taking care of the economic development of Galicia, Metropolitan purchased several estates, which were divided among the peasants. He was an initiator and co-founder of the "Land Mortgage Bank" in Lviv (1910), which loaned peasants money for the land they acquired. By contributing to the parceling of large land holdings, A. Sheptytsky aimed not only to solve the purely economic problems of the region, but also to develop agricultural science, to spread its achievements among various, especially the poorest, sections of the population. In the divided folwark at the Korshiv village, near Kolomyia, the company "Agricultural Master" became the owner of the land, on which the bakery school was founded. In Mylovan, near Tovmach, a yard and several dozen morgens of the field were obtained were given to "Prosvita" for the establishment of the first Ukrainian horticultural school; the summer camp for children from poor families also worked there. In Sknyliv, the courtyard and the large garden were occupied by the students, who open workshops of handicrafts, mechanics, and so on. In Zarvanytsya, 300 morgens were given to the students for farming and 250 for the orphanage. M. Marynovych made the most complete and thorough analysis of Metropolitan's pastoral messages on economic topics ${ }^{191}$.

The above list clearly characterizes one of the main directions of A. Sheptytsky's multifaceted activity - his constant concern for the future of the nation - children, especially orphans. He helped the kindergartens and orphanages. The first Ukrainian Women's Gymnasium "Native School", where Basilian sisters gave orphan girls a secondary education, was built at his expense. Not the Polish government, but Sheptytsky after the First World War gathered orphans to give them custody. Spending a million dollars, he arranged several orphanages for them, where they were educated and mastered with various crafts.

190150 думок Митрополита Андрея Шептицького / Упор. Тереза Ференц. Львів: Свічадо, 2015. С 58.

${ }^{191}$ Маринович М. Митрополит Андрей Шептицький і принцип «позитивної суми» / передмова Андріана Сливоцького. Львів: Видавництво Старого Лева, 2019. 248 с. 
Every year Metropolitan conducted a wellness campaign for poor children. He built a number of houses for children in Pidliuta of the Dolyna district, among the Carpathian forests. Here in great climates and under the tutelage of good educators, several thousand children between the ages of 4 and 14 have gained strength and intelligence. Here they were taught prayers, history, Ukrainian studies, Ukrainian language and behavior.

Health problems also played a prominent role among A. Sheptytsky's interests. In September 1903, he founded the People's Hospital, which later turned into an extremely huge hospital. The impetus for its creation was the activity of a doctor E. Ozarkevych, who, concerned about the fact that Ukrainians were not accepted to Polish hospitals, dreamed to open a Ukrainian hospital, where our doctors would acquire and improve difficult medical professions. To this aim he founded a voluntary medical society in 1903. Metropolitan supported the initiative, provided considerable financial assistance, formulated the direction and scope of its activity: "for the lower and suffering humanity without difference of nationality". Treatment and medication were free. Nursing courses were opened at the Theological Seminary, 228 girls graduated, and, as a result, the hospital was provided with its' support medical staff ${ }^{192}$.

However, this hospital was not the only one that functioned at A. Sheptytsky's expense. In 1925, in the Yaniv suburb of Lviv, he transferred a house for the branch of the Lviv medical clinic - the "Society for the Tutelage of Youth", where the "Mothers' Advice" was also located. In the village of Pidliute, on the territory that belonged to Metropolitan, a sanatorium, based on sulfur-iodine sources, was organized. In the Sokal district, in the mountains, in cooperation with the "Teachers' Community", a permanent "Plast" camp functioned at his expense, and in 1911-1912 the students' medical community, with his assistance, created a sanatorium for the students ${ }^{193}$.

Admitting the healing value of nature, A. Sheptytsky took care of its protection. In 1925 he was elected a member of the Shevchenko Scientific Society. At the request of the Commission of Nature Protection under the Shevchenko Scientific Society, Metropolitan ordered to create on the lands of the Lviv metropolis a reserve of cedar forests on the Egg Mountain near Pidliute and the steppe vegetation near Devil's Mountain (in Rohatyn Parish). These were the first nature reserves established in Ukraine.

${ }^{192}$ For more details see.: Заборовський Я. Ю. Нарис про життя і служіння церкві та народові (1865-1944 рр.). Івано-Франківськ, 1995. С. 19-20.

193 Медики і медицина в житті та діяльності Митрополита Андрея Шептицького (До 150-річчя від дня народження): бібліографічний покажчик / уклад. М. С. Надрага, О. М. Кріль, С. В. Васільєва, Л. С. Метельська; наук. ред. А. В. Магльований. Львів, 2015. 94 с. 
However, most of all, Metropolitan Andrey was interested in the cultural development of the Ukrainian people, their education and upbringing. He assisted artists, choral art, church and folk art and other societies and communities. Metropolitan established dozens of scholarships, which gave the opportunity to hundreds of young men to get education as a medical doctor, a lawyer, a teacher in the universities of Western Europe. He helped H. Krushelnytska, F. Lopatynska and A. Hayek to receive an art education. A. Sheptytsky purchased a separate room for Lviv artists (the villa of Polish artist J. Styk), where the art school of O. Novakivsky and the workshops of M. Sosenko and O. Kurylas were located. The culmination of the cultural and educational activity of Metropolitan A. Sheptytsky was the founding and material support of the "National Museum" in Lviv. In 1905 he founded a Church museum in Lviv, which the curatorium renamed as the National Museum nfmed after Metr. A. Sheptytsky. For this museum A. Sheptytsky bought 15 thousand exhibits, paying two million kroons. Sheptytsky managed to buy a magnificent palace for a museum for 34,000 USD, though the owner-chauvinist didn't want to sell it to Ukrainians. On December 13, 1913 Sheptytsky presents a unique collection of Ukrainian art of the XIXX centuries to the museum. Art historian Hilarion Swiencytsky organized the museum exhibits, making the National Museum the largest treasure in Ukraine: by 1939 it had more than 80,000 exhibits in 10 departments, it published 16 volumes of scientific notes, and organized about 70 exhibitions. The museum had a unique library: more than 30 thousand volumes of albums from different sections of Ukrainian studies and art history. According to K. Korolevsky, the catalog of ancient Slavic books, published by I. Swiencytsky could "compete with a similar Russian edition made by Karatayev" $" 194$.

It is important to note that A. Sheptytsky considered art not only as a prominent means of forming the general cultural level of the people, but also as one of the main factors in the upbringing of a nationally and religiouslyconscious society. This is clearly evidenced by his letter-message of April 25, 1941, "On Church Singing" and by a letter of August 8, 1942, to prof. V. Kubiyovych on the project of the art school for drawing teachers. "Undoubtedly", he writes in the letter, "an awakening factor in education is the awakening of the aesthetic sense and the cultural direction that education gives to that sence. But drawing teachers, Ukrainians, have a second overriding importance: they must give a noble and sublime direction to patriotism... Our young people, who had to go to the Polish secondary

${ }^{194}$ Королевський К. Митрополит Андрей Шептицький (1865-1944). Львів: Свічадо, 2016. C. 107. 
schools for a long time, often have no idea about the most important figures of the Ukrainian people. We do not yet have the illustrated history of Ukraine, but we have famous and great artists, about whom the youth has never heard of in the ordinary, even Ukrainian high school. We have such Murashko, Narbut, Novakivsky, even Repin, and, in the 19th century, Levitsky. Only a drawing teacher can acquaint the Ukrainian youth with them, and only wise and well-educated drawing teachers can awaken in the Ukrainian youth the talents and artists, who would show us how Khmelnytsky or Mazepa looked like. Or, better to say, not only how they looked like, but how they should look in our thoughts, hearts, concepts" ${ }^{\prime 195}$.

Metropolitan Andrey Sheptytsky made great efforts to develop a system of national and religious education, which was attached by him to a great importance. In his first pastoral letter to the believers of the Stanislaw Diocese of August 2, 1899, "The First Word of the Shepherd" the future Metropolitan states that education is more valuable than wealth ${ }^{196}$. As mentioned above, Sheptytsky constantly took care of secondary education, Institutes' education of the Ukrainians, and not only in the territory of Galicia. In particular, thanks to his personal mediation, the Ukrainian Economy Academy in Podebrady was saved from liquidation by the Czech authorities.

Naturally, Metropolitan paid the highest attention to the development of spiritual education. The seminaries in Przemysl and Stanislaw were built with his help. The last one, when opened in 1906, was given perhaps the most valuable gift -4000 books from Sheptytsky's personal library, among them many rare and ancient editions and manuscripts. On September 1, 1901 a pastoral letter was issued with a plan for the complete reconstruction of the Lviv Grand Seminary, which was central to all of Galicia: almost a third of the teaching staff and the board were renewed, and the Seminary rules were simplified.

However, "feeling that the results of this reorganization will be slow, Metropolitan for his family money often sends the best seminarians to theological studies in Rome, Innsbruck and Augustineum (in Austria), Friborg (Switzerland). Soon these efforts gave a successful result and the most important ecclesiastical positions were held by people of European

195 Митрополит Андрей Шептицький: Життя і Діяльність: Документи і матеріали 1899-1944. Т. ІІ. Церква і суспільне питання. Кн. 2: Листування. Львів: Місіонер, 1999. C. $978-979$.

${ }_{196}$ Владика Андрей. Альманах «Гомону України» на рік 1994. Торонто - Онтаріо, 1994. C. 44. 
education (no lower), and often much higher than in other Catholic dioceses of Western Europe or America" ${ }^{197}$.

It is important to note that A. Sheptytsky never divided education into "purely religious" and "purely secular", on the contrary, he constantly emphasized their interdependence and interconnectedness. Metropolitan sought to equip the clergy and believers not only with theological knowledge, but also with "sufficient knowledge of Philosophy, Sociology and Political Science, world general science", to give impetus to the development of Law education, because he rightly believed that "in our people there is a general lack of a clear and firm sense of law, ... a lack of talented legislators between our people, because even a famous lawyer can be a weak legislator" 198 .

Metropolitan A. Sheptytsky's ideas were largely realized in the activities of the Theological Academy, founded by him, which opened on October 6, 1929. in Lviv. At that time it was the first and only one higher theological Ukrainian school, which was to continue the traditions of the Kyiv-Mohyla Academy, on the one hand, and on the other, to be guided by the models of foreign theological schools. A few years later Academy became not only an important center of theological sciences, but also a center of studies in history and literature.

A. Sheptytsky was not only the founder of the Academy, but he also constantly took care of it, participated directly in its activities. Since 1933, he taught the asceticism of the Western and Eastern Churches. He appointed as the Academy's rector such a prominent religious and cultural figure as the future Cardinal J. Slipyi ${ }^{199}$. Metropolitan involved the most famous scientists, who were in Galicia at that time, into the scientific activity and into teaching at the Theological Academy: lawyers L. Hlynka, R. Kovshevych, O. Nadrag; art historians V. Sas-Zalozetsky, I. Svencitsky; historians I. Krypiakevych, M. Chubaty, V. Struten; philologists V. Sonevytsky, K. Chekhovych; archaeologist J. Pasternak; geologist Y. Polyansky; philosopher M. Konrad; physician Z. Hordynsky; anthropologist I. Rakovsky; sociologist B. Kasymyr. This list is far from complete, but it makes it possible to evaluate the wide range of teaching courses taught at the Academy.

It is no wonder then, that contemporaries treated the development of the Academy as a nationwide affair, as an important step towards the creation of

197 Заборовський Я. Ю. Митрополит Андрей Шептицький. Нарис про життя i служіння церкві та народові (1865-1944 рр.). Івано-Франківськ, 1995. С. 18.

${ }_{198}$ Шептицький Андрей. Листи-послання (1939-1944). Львів, 1991. С. 33-34.

199 Ленцик В. Визначні постаті Української Церкви: Митрополит Андрей Шептицький і Патріярх Йосиф Сліпий. С. 429-446. 
a new Ukrainian national university. The Academy lived up to these expectations. "The national tasks of the academy," was written in the journal "Our Call", "in the sphere of preparation for the social work... are, to some extent, accomplished. Graduates of the Academy are well-versed in all major movements of philosophical thought and in the major problems of sociology, and can well fulfill their role as leaders and organizers of different sections of our national life. Some knowledge of modern law will be a good weapon for them in the modern struggle for the individual and national interests of those Ukrainians, among whom they will have to work. Knowledge of Ukrainian ecclesiastical art and archeology among the younger generation of Ukrainian clergy can be helpful in the case of preservation from destruction of many valuable monuments of our ancient culture and it can be helpful in the creating of our museums" 200 .

However, it was not destined for the Theological Academy to turn into a national university, as A. Sheptytsky wanted it. The Polish chauvinist authorities vetoed this plan by Metropolitan, declaring that they would not recognize diplomas from such an educational institution. It should be noted that this was not the first and, unfortunately, another failed attempt by Metropolitan to create a Ukrainian National University in Lviv. As early as 1908, at the Pan-Slavic Congress convened in Prague on his own initiative, a resolution was proposed to promote the opening of a university in Lviv. It was failed at the suggestion of the head of the Russian delegation V. Bobrynsky, who was then a member of the State Duma, leader of the National Party, and later, during the World War I, as a governor of Galicia and Bukovyna, became famous for his Russification policy and, in particular, for the deportation of Metropolitan A. Sheptytsky to Russia ${ }^{201}$.

A. Sheptytsky's great speech of June 28, 1910 at the 11th meeting of the 22nd session of the Imperial Council in Vienna, where he presented the case of establishing a Ukrainian university in Lviv, became very famous not only in Galicia, but also throughout Western Europe. The deep argumentation, given by A. Sheptytsky, influenced the authorities, and despite the opposition of the Polish ruling circles in 1913, as well as the official note of the Russian ambassador in Vienna, where the opening of the Ukrainian university was called a "hostile act" towards Russia, the Emperor issued a decree on the opening of such a university on September 1, 1916. Unfortunately, these plans of A. Sheptytsky failed to materialize because everything was crossed by World War I.

\footnotetext{
${ }^{200}$ Наш клич. 1933. 16 квітня.

${ }^{201}$ For more details look: Митрополит Андрей Шептицький і греко-католики в Росії. Книга 1: Документи і матеріяли, 1899-1917 / Упорядкували Юрій Аввакумов і Оксана Гайова. Львів: Видавництво Українського Католицького Університету, 2004. 924 с.
} 
Metropolitan Andrey Sheptytskyy did not limit himself only by patronage and organizational activity in the field of culture, education and science. Three times the doctor - of theology, philosophy and law - he was a scientist of the European scale, and he had considerable personal scientific achievments ${ }^{202}$.

Paying particular attention to the problems of education and pedagogy, A. Sheptytsky was aware that the grounds of any system of national education are spiritual, philosophical and methodological foundations. They are intended to determine the meaning and valuable orientations of pedagogical activity, as well as the relationship between the universal, national and personal in the "human-world" system.

In existential terms, education as a cognitive aspect of human being and as a concept is much broader in its content than institutionalized activity within its specific historical forms, it is one of the aspects of human education. This understanding of education and the detailed development of the philosophical foundations and moral principles of educational activity can be found in the works of A. Sheptytsky.

Referring to Ukrainian youth, Metropolitan wrote: "You go to every kind of school... you do well when care for education and knowledge. Because, after Christian righteousness and the grace of God, knowledge is the greatest power that man can command" 203 .

It is important to emphasize that, while highly appreciating education and science as a manifestation of the cognitive activity of the human mind, A. Sheptytsky constantly pointed to the interconnection of the goal and the ways of education with Christian principles, the very essence of Christianity. Already at the beginning of his Metropolitan activity, in 1901, worried about the spread of religious indifference, agnosticism and atheism in the circles of educated Ukrainians, he wrote a special pastoral letter to the Ukrainian secular intelligentsia, explaining why Christianity is still important in the age of rationalism. "Jesus Christ and His Holy Church", he stated in another pastoral epistle, "is not at all opposed to science and enlightenment. On the contrary, they spread and spread it" ${ }^{\text {204 }}$. To support this words A. Sheptytsky cited numerous statements of Jesus Christ, in which he called himself "the light of the world", "the Truth", the "way" and for the purpose of his coming into this world he considered freedom for people, which they could attain through enlightenment, if they will understand the testimony of truth.

202 Ленцик В. Названа праця. С. 195-205; його ж: Слуга Божий митрополит Андрей Шептицький та українська наука. Богословія. Т. 55. Рим, 1991. С. 166-181.

${ }^{203}$ Шептицький Андрей. Листи-послання (1939-1944). Львів, 1991. С. 6.

204 Твори слуги Божого Митрополита Андрея Шептицького. Пастирські листи (2. III. 1899 - 7. IX. 1901). T. 1. Торонто, 1965. C. 5. 
Therefore, "education is about one thing: knowledge should be a true knowledge, it should relate only to the truth, and not to falsehood, not to lies. True knowledge is the power of human and false knowledge, based on iniquity, is a true ailment for a human, an injury and a misery for the whole life, ${ }^{, 205}$.

Linking the progress of European culture with Christianity, which freed people from the darkness of paganism, A. Sheptytsky noted that true culture and education in Ukraine have Christian roots. "In all our history", he wrote, "you will not find an era of such great and such impetuous progress in culture and education as it was during the time of St. Volodymyr the Great, when Rus-Ukraine adopted Christianity" 206.

With the primary aim of achieving an organic union of national revival with the spiritual revival, Metropolitan rightly believed that "there is no greater sign for our people today, as unity, and no more important work for our clergy than the work on national and Christian unity of the people"207. The precondition for such unity is the awareness for all strata their common interests, regardless of party or congressional affiliation. In order to achieve such a situation, in his opinion, Ukrainians, first of all, should abandon their provincialism and rise to the level of the world culture and seek solutions to their problems on the basis of human values and Christian morality. Science and education must say their weighty word in the case of formation of the national consciousness. Meanwhile, A. Sheptytsky states with annoyance that the question "where is everything that makes the Ukrainian people a human organization so infinitely far from the natural organism, that our community seems more like a pile of sand, single grains of which have nothing to do with the others, than a mighty tree, in which life develops, full of strength and health", this question remains open, because "we either have very few or do not have at all any philosophers or moralists who would study our national psyche",208.

This situation is also typical for the other spheres of national and social life, in particular, for politics. "In many ways, we are still primitive people, for whom demonstration, phrase and noise often seem more important than quiet cold thought and long-lasting work. In our society there are too many people, who consider themselves professional politicians, although they have no specialty and no specialized knowledge. This situation itself changes professional work into rhetoric ${ }^{209}$.

\footnotetext{
${ }^{205}$ Шептицький Андрей. Листи-послання (1939-1944). Львів, 1991. С. 6.

${ }^{206}$ Шептицький Андрей. Листи-послання (1939-1944). Львів, 1991. С. 6.

${ }^{207}$ Ibid. C. 408.

${ }^{208}$ Ibid. C. 409.

${ }^{209}$ Ibid. C. 410.
} 
On what basis should a system of national education, that would overcome our "primitive patriotism", be built? In general terms, A. Sheptytsky tries to answer this question in the great theological work "Christian Righteousness", where he thinks about the nature and interconnection of knowledge, wisdom and faith, theory and practice, where he reveals the connection of these epistemological concepts with the category of good.

By the natural human knowledge he understood the right reasoning about things, which are gained with experience and with the reasoning of that experience. Wisdom is the knowledge of the highest cause of all, of God, it is the highest and most perfect knowledge, which does not come from human experience, but is a reflection of God's knowledge. Faith itself applies to wisdom and to human knowledge. The source of faith is the first truth, God. Human knowledge is not so directly related to God. However, in another sense, faith, as a revealed truth, is linked to knowledge, because in the process of knowing one is free to choose what to believe in and what to believe not ${ }^{210}$.

The concept of faith is also considered in relation to the categories "theoretical-practical". Faith as a reflection of God's truth is attributed to theory, because the human mind is united with God through it. At the same time this truth of God is the supreme goal of cognitive activity, a kind of theoretical ideal for which practical activity takes place. Faith emerges as a concept that encompasses both theory and practice. The theoretical (higher) knowledge, obtained through faith, is the first and the most important, because it relates to the truth of God. However, the appropriate practice, that is predetermined by this truth and is in need of this truth, is a very important moment in people's lives, as it is related to human progress.

The epistemological categories of knowledge, wisdom, faith, theory and practice, which are being in some moving intercconections, turn out to be a system, the structural element of which is the category of grace. In this system a true knowledge cannot be in a soul, which has no grace. So is with faith. Only a person, sanctifyied by grace, can know what to believe in (theory) and how to act according to that belief (practice). Therefore, human cognitive activity can be righteous and successful both in its immediate and subsequent consequences only if it is combined with grace.

Thus, the philosophy of education, proposed by A. Sheptytsky in the work "Christian Righteousness" proves logically, harmoniously and

${ }^{210}$ Шептицький Андрей. Християнська праведність // Шептицький А. Твори-ореча. Рим, 1978. С. 258. 
philosophically that between knowledge and wisdom, knowledge and goodness, theory and practice there should be no antagonistic contradictions.

On the contrary, knowledge becomes a true knowledge only when the logical-epistemological (theoretical) and praxeological (practical) aspects are combined with axiological (valuable), and when they are interpreted by the understanding of good (grace). In fact, the separation of human knowledge from its spiritual and moral foundations, the loss of good (grace) as the main reference point, leads to the "pride of mind", which is a direct path to the "trouble from the mind", an example of what is the current ecological state.

A. Sheptytsky assured that knowledge should not be a weapon, it is not a force in the positivist sense of the term, it is the basis for the ascension to a higher wisdom - Divine revelation through spiritual self-perfection. "The wisdom of God is the best, highest and most valuable sign of the human mind. It is the reason that a wise child stands higher than a man, who undertakes to teach others. Such a child may not have all the information, he possesses, but if he does not have the Wisdom of God, then the child exceeds him with the bright, clear and powerful sign of mind that puts that child above his intellectual conditions of life. The power of the mind and its light is not in knowing many details, but in knowing well what is known, in being as far from errors and deceptions as possible, and in having the most correct notions of common questions, bypassing, perhaps, millions of details about the conditions, the one cannot get in. The one who knows that our earth is a ball and it rotates around the sun, knows much more than the one who does not know this, but he cannot count all the grasses and their roots on the whole morgen" 211 .

This somewhat long quote clearly shows how far Sheptytsky was ahead of his time in his understanding of the process of knowledge. After all, he lived and created at a time when in European (and not only European) philosophy, science, education, almost individually dominated the various streams of positivism, in which knowledge is reduced to experience. For Sheptytsky cognition is an active process of consciousness activity for knowledge production. To know is not only to get certain information about the object, that is being studied, but also to understand its meaning. Information activity, which is often reduced to knowledge, is only a technical work of the mind. That is why cognition should be taken in the unity of informational and mental (hermeneutic) activity. However, this is not enough. At the end of the XX century humanity has finally realized that cognition must answer not only the questions "how?" and "why?", but also the question "what for?", it means that it has to carry self-esteem from the

${ }^{211}$ Шептицький Андрей. Листи-послання (1939-1944). Львів, 1991. С. 7. 
standpoint of good and evil. It is on this integrity of the process of cognition, that A. Sheptytskyy focuses his attention.

Later A. Sheptytsky repeatedly returned to these problems. In particular, in the Decree of Ep. Council (1942) "On Liberal Conscience", written by Metropolitan, he thoroughly analyzed such concepts as psyche, consciousness, conscience and morality. He points out that in some languages, including Greek and Latin, the definitions of conscience and consciousness are denoted by the same word. In the Ukrainian language these two definitions are also combined, though they are denoted by different words: so-vist (conscience), so-vidomist (consciousness). The word "sumlinnia" (conscience) consists of the same two roots - so-mninnia. Therefore, conscience should be considered as a special kind of consciousness - moral consciousness. The definition of "consciousness" in its own sense is used only to define psychological consciousness. The latter "is the sum of those observations that a person makes, while paying attention to its psyche, its inner life. It is an observation of internal phenomena, of impressions, expressed by thoughts, feelings and expressions of desire and manifestations of thinking and understanding,"212.

Such internal observation, on the one hand, is self-awareness, a state of consciousness, when the human personality is both an object and a subject of cognition. On the other hand, consciousness cannot be reduced to selfobservation: a person "only in the work observes the manifestations of actions, thoughts, desires, feelings, impressions, meanings, but it has no consciousness, no will, no mind or power to withdraw impressions from the outside world" ${ }^{213}$. Therefore, the way to comprehend the powers of the soul, of own spiritual intelligence, lies through the study and understanding of the external manifestations of these powers.

A. Sheptytsky, however, states that even after going through a long and difficult path of knowledge, after discovering the presence of a spiritual being in itself, after reaching the concepts of spirituality, complexity, intelligence, immortality, etc., a human being still remains an unknown abyss for itself, an unsolved mystery, because the nature of spirituality remains beyond the limits of conscious, in the realm of the unconscious.

The supernatural world also belongs to the unconscious of a human being. The grace of God as a state, the virtues, gifts of the Holy Spirit as the power of the soul are not known in themselves, but become the object of knowledge only in actions, manifestations, and are revealed through experience and reasoning in a vague, unclear, incomplete form.

${ }^{212}$ Шептицький Андрей. Листи-послання (1939-1944). Львів, 1991. С. 310.

${ }^{213}$ Шептицький Андрей. Листи-послання (1939-1944). Львів, 1991. С. 311. 
Finally, the sphere of the unconscious includes the manifestations of the organic nature of man, as well as the acts of will or reason that occur in the subconscious.

Thus, the psychological consciousness is not identical at all to the psyche, and even more - to human spirituality, it has certain limits of existence. However, the boundaries between the conscious and the unconscious are not inviolable, they depend on the abilities, experience and general education of man.

According to A. Sheptytsky, psychological observations are grouped around two objects of knowledge: on the one hand - an unchanging being, God as the Absolute-Being and the reason for everything that exists; on the other hand - the outside world, first of all - the human society. At the same time, psychological consciousness is not reduced to a simple, more or less clear, statement of the presence of phenomena and their signs. In this consciousness the object of knowledge is also our relation to God and to the outside world, to other people. "In these observations, consciousness passes into conscience, in relations with God and other people we also observe our responsibilities. Conscience is the consciousness of the moral side of our relations to God, to ourselves and to people. Just as psychological consciousness explores, understands, seeks knowledge of internal phenomena, so does conscience explore those signs or shortages that make our actions morally good or evil. It is - our actions with the knowledge of the rules of that action, with the natural law" ${ }^{214}$. The law-maker of the natural order - law is God.

As already noted, psychological consciousness depends on the speed of reason, on the gift of observation, on education and personal experience. Conscience, in addition, is also influenced by passions, human habits, the influence of the environment, education, moral atmosphere. That's why conscience embraces a narrower circle of phenomena of inner life than consciousness.

Moral principles, and especially the rules of applying them to life, do not lie on the surface, their awareness, their transformation into conscience requires the work of the mind, which is not always sufficient. This leads to false forms of conscience. One such form of false conscience is, according to A. Sheptytsky, a liberal conscience that denies or diminishes the meaning of moral laws, based on the individualistic principle of permissiveness. What is the result of this position is well demonstrated in the novels, written by Fyodor Dostoyevsky. However, the liberal conscience also had its apologists, the most famous of whom is F. Nietzsche. His superhuman,

${ }^{214}$ Шептицький Андрей. Листи-послання (1939-1944). Львів, 1991. С. 312. 
blond bestia is the result of this very understanding of conscience: God is dead, so he is God himself, that is, the creator of morality.

Drawing attention to the danger of such perversions of conscience, A. Sheptytsky asks pastors and all believers to fight them. The bearer of the liberal conscience "reverses the moral order: instead of judging one's wishes according to the prescriptions of the conscience, one judges the duties of the conscience according to the prescriptions of one's desires. Sin becomes a second nature, the element, in which man lives, and when there are still traces of faith in him, he slowly applies the truth of faith to his way of life, transplanting the mercy and goodness of God and attributing to the Almighty the granting of such freedom, which only his own liberal conscience allows" ${ }^{215}$. That's why such conscience leads to a state of deep moral decline and is a severe illness of the soul, which is difficult to treat.

At the same time, A. Sheptytsky states that liberal conscience should be distinguished from the broad conscience. "The broad conscience, how it is called by the theologians, is a wise and peaceful judgment, which, in some circumstances or for some good reasons, is not bound by human law"216. In other words, it is a conscience that is based on the so-called principle of probabilism, the essence of which is that not all moral norms have the meaning of natural, divine law and are eternal, some of them are created by humans and, therefore, can be rationally rethought, refuted and changed in the process of the historical development of mankind. However, broad conscience never leads to the denial of morality as such, which distinguishes it from the the liberal conscience.

Another very important mistake in the science of conscience, according to A. Sheptytsky, is the fact that "conscience replaces the moral law and conscience is considered to be a single rule of moral action with the objection of objective rule, which is the law" ${ }^{217}$. Such an error is peculiar to atheism, which, inspite of its contrudiction to God's laws, acknowledges the existence and necessity of moral norms in human society. Nevertheless, moral standards must have the feature of law, which means, that they should be universally recognized and universally respected. Such status, according to atheists, is given to them by social will, public opinion. According to A. Sheptytsky, such social morality inevitably acquires the character of an imperative, an absolute, which means that it doesn't allow not only disobedience but also criticism, and declares everything, that does not recognize it, a crime. In its relation to individual

\footnotetext{
215 Шептицький Андрей. Листи-послання (1939-1944). Львів, 1991. С. 314.

${ }^{216}$ Ibid. C. 313

${ }^{217}$ Ibid. C. 318.
} 
consciousness, it will have the character of coercion, and not a voluntary duty, without which, in fact, there is no morality.

However, public opinion is not absolutely timeless, it is changing, and its declared generality cannot be a guarantee against error. "History also teaches how general thought bent in front of tyrants and how its outside look differed for its inside look" ${ }^{218}$. In addition, a society, where all social groups and the individuals would be in total agreement on all moral principles, does not exist at all.

Thus, taking morality as the basis for public opinion, atheists, in the first place, inevitably come to deny the existence of unchanged and stable moral norms, and, secondly, they "dissolve" the individual in the society, make him a little screw in the social system.

Analyzing this issue, A. Sheptytsky raises an actual problem of the modern society. In the philosophy of morality from the time of Hegel, it is customary to distinguish between moral and morality. Special attention to this distinction was paid by the prominent Russian philosopher V. Solovyov, with whom A. Sheptytsky was personally familiar in his younger years and who influenced both the formation of the outlook and the choice of the life path of the future Metropolitan ${ }^{219}$, which will be discussed further. According to Solovyov, morality is always corporate - it includes the principles of behavior of a particular community (class, nation, etc.), which are based on certain preferences. Moral is universal - it includes the tenets of behavior of the individual as part of the human race. Moral is an absolute morality, one at all times for all nations, for all mankind. Solovyov calls it God. That is why talking about class or national moral is groundless.

Corporate morality knows such definitions as "our", "stranger", "friend" and "enemy". And from here - if the enemy does not surrender, he is destroyed, and if he surrenders - he's also destroyed, together they destroy both the potential enemy and, in general, the suspects. Morality recognizes the absolute importance of each individual, regardless of their predicates and corporate affiliation. The murder of a savage, says Solovyov, is the same crime as the murder of a genius and a saint ${ }^{220}$.

${ }^{218}$ Шептицький Андрей. Листи-послання (1939-1944). Львів, 1991. С. 319.

219 His Beatitude Lubomyr Husar noted in his doctoral dissertation: "The influence of V. Solovyov on A. Sheptytsky cannot be denied. The similarity of the ideas of these two men is striking, so we can simply say that A. Sheptytsky learned a lot from V. Solovyov. He did not take V. Solovyov literally, did not follow him in everything, but the general vision of the unity of the Church and the unification of the Churches was clearly borrowed from Solovyov" (Гузар Любомир. Андрей Шептицький Митрополит Галицький (1901-1944) провісник екуменізму. С. 59).

${ }^{220}$ For more detail see: Соловьев В. С. Спор о справедливости: Сочинения. М.: ЗАО Изд-во ЭКСМО-Пресс, Харьков: Изд-во «Фолио», 1999. 864 с.; Соловьев В. Россия и Вселенская церков. Минск: Харвест, 1999. 1600 с.; Соловьев В. Чтения о богочеловечтве. Духовные основы жизни. Оправдание добра. Минск: Харвест, 1999. 912 с.; Соловьев В. 
Such a position is completely shared by A. Sheptytsky. In his view, neither individual nor social conscience can be the basis for moral sanctions. These sanctions belong only to a conscience, which is based on the acceptance of natural and divine law.

According to A. Sheptytsky, synthesis of psychological and moral consciousness is achieved through the unity of education and pedagogy. Therefore, the problems of education have always been in the focus of Metropolitan's attention, and he constantly mentioned them in his pastoral messages. A kind of generalization of his views was the speech "On education", proclaimed at the Ep. Cathedral in 1942. Basing on this report, on December 10, 1942 Cathedral adopted the Rules "On the Education of the Youth", which were developed by Metropolitan and, in his expression, they form a small code of Christian education. It should be noted that A. Sheptytsky himself considered this work far from complete and planned to return to it in a few years ${ }^{221}$.

According to A. Sheptytsky, education is not only extremely important but it is also extremely difficult. It is "the highest and wisest problem a person can meet" ${ }^{, 22}$. Therefore, following Hryhory Nazianzin, Sheptytsky calls education "the art of the arts" and "the knowledge of all knowledge".

The purpose of education, according to A. Sheptytsky, "is such a development of the child that he or she would become an adult with developed and carefully nurtured all the possibilities of mind, will and heart. That development depends, obviously, on the concept of a person, who is the leading mistery of education. This concept again depends on the whole outlook that a human has to live with"223.

A. Sheptytsky distinguishes three types of outlook that determine the appropriate directions and ideals of the educational process. The first is the materialistic, in which man is treated as a natural being, and therefore education is directed to develop the abilities and forces that a man has to have to meet material needs.

The second is the humanistic outlook. Here, a man is the supreme autonomous being capable of endless development of science, art and culture. The bearers of this worldview in education will seek the development of all human nature with all its attributes and powers, they will do it to flush out the bearers of the highest and most comprehensive

Философское начало цельного знания. Минск: Харвест, 1999. 912 с.; Лосев А. Ф.

Владимир Соловьев и его время. М.: Молодая гвардия, 2000. 613 с.

${ }^{221}$ Шептицький Андрей. Листи-послання (1939-1944). Львів, 1991. С. 255-257.

${ }^{222}$ Ibid. C. 255.

${ }^{223}$ Ibid. C. 231. 
civilization; will nurture a comprehensive knowledge, poetry and all kinds of art, creative or critical ${ }^{224}$.

The third type of outlook is Christian. In it, a person is treated as a child of God, combining natural and supernatural, and education is directed to the development of all the virtues of the Christian life, the most important of which is love for one's neighbor.

A. Sheptytsky draws attention to the fact that human love is twofold: one is the love of reason and will, the love, that Christians have to love all their neighbors; second - is the love of the heart, which encompasses all human nature and soul, it is not a subject to the order of will. "...This is the love that people naturally love their closest ones - it is the love of family, of relatives to children, of children towards relatives and among themselves. It is the love of friends and fellows, it is the love of own people"225.

The love of the mind and the will is more complete in the nature that is not spoiled, but because of perversity of human nature, because of original sin, there is a rebellion of passions against reason and will. Therefore, only the love of heart is truly Christian. According to A. Sheptytsky, this is indicated by the fact that in the Holy Scripture God represents His love to the people in expressions and images that are inherent to a human love of heart.

"The love of one's neighbor, and rather the love of God", emphasizes Sheptytsky, "the love, which embraces all our neighbors as the children of God, or at least called to become the children of God, this love raises man above all creation, above the whole material world, and teaches him, in the example of Jesus Christ, to give even his own life for salvation, for the life of neighbors. The top of that love reaches to heaven, but its foundation rests so much on human nature that there is no man, who would not feel the need for love in that natural inclination of the human heart for compassion and mercy"226.

Thus, the love of the heart is the supernatural nature, the embodiment of God's grace. However, the concept of the heart, which is widely used in theology and philosophy, but often in different meanings, needs to be invaded here. In his understanding of this concept A. Sheptytsky relies not only on the theological tradition, where, by the way, there was no unanimity in its interpretation, but also continues the traditional for the Ukrainian philosophy cordocentric line, which dates back to the times of Kievan Rus, but finds its highest incarnation in the works of $\mathrm{H}$. Skovoroda and

\footnotetext{
${ }^{224}$ Шептицький Андрей. Листи-послання (1939-1944). Львів, 1991. С. 232.

${ }^{225}$ Ibid. C. 136.

${ }^{226}$ Шептицький Андрей. Листи-послання (1939-1944). Львів, 1991. С. 168.
} 
P. Yurkevych. He rightly believes that the appeal to this concept will solve the eternal problem that "divides the philosophers of antiquity, the Fathers of the Church, and all theological schools into two opposing groups, which are only rarely complemented: on the one hand, the intellectualist Aristotle and all the intellectualists of the Christianity with St. Thoma and the thomists, and on the other hand, all mystics from Plato to Bonaventure and the followers of Duns Scotus. The problem that divides them is next: whether the center of the human psyche is mind or will, intellect or affect"227.

The same problem, though in a different aspect, is inherent, in Sheptytsky's view, to a modern theology and philosophy: identifying the concept of the heart, including Christ's, with a certain physiological organ, whish is done by some representatives of theology, leads to their confrontation with philosophy and science, "because modern philosophers place love, hatred and other affects of the spirit not in the heart as a centre, but in the brain" 228 .

The reason of the problem, according to A. Sheptytsky, is that there is a change in the content of concepts: the heart as a symbol for defining the inner spiritual life of a person begins to be understood as a certain material organ, and this, in turn, leads to the identification of psyche and soul, that is, in fact, to denying the latter. In addition, a human as a person is integrity, and this integrity is emphasized by the concept of "heart", which characterizes a certain synthesis of such spiritual essential forces as reason, feelings, will, etc. Therefore, it is unlawful to take a one-sided approach to determining the essence of man, proclaiming him the bearer of reason or will, reducing the essence of man to the totality of social relations, or, conversely, extorting his fundamentally asocial individualistic-biological nature.

These are the theological and philosophical foundations of Christian education, which must make a person "a holy citizen of heaven". A. Sheptytsky, however, notes: "Education itself, obviously, cannot do everything; the will of the man and his work over himself are very much involved. But to encourage him to do the work, to teach him to work properly over himself, to instill the love of that work in his heart and to enrich his mind with the knowledge of everything that is needed for that work, is the task of education" 229 .

The main link in education should be the family, because "the Christian family is a school of Christian life, and also a school of mutual, national and

\footnotetext{
${ }^{227}$ Ibid. C. 142.

${ }^{228}$ Шептицький Андрей. Листи-послання (1939-1944). Львів, 1991. С. 140.

${ }^{229}$ Ibid. C. 232.
} 
universal life. For how long this school is healthy, for how long it gives out numerous and healthy units - for so long the people are both healthy and strong" ${ }^{230}$. However, the process of upbringing is not limited only to the family. Moreover, A. Sheptytsky is aware that in our time, for various reasons - circumstances of life, public school, etc. - the family has no proper influence on the upbringing of children. Therefore, in his concept, he gives a thorough analysis of the other elements and foundations of education.

To the main elements of education A. Sheptytsky includes, first, suggestion, that is, the influence of the environment on the child; secondly, science and, thirdly, the Christian atmosphere.

Suggestion is caused by the fact that a human by its nature is a social creature, therefore it is able to imitate others, to fall under the influence of the environment as a whole, and of individuals, and therefore it is not independent in concepts and actions. The value of the environment is extremely important, because it is mainly involved in the formation of outlook. The central place in this process belongs to the family, but the street, the school, the older comrades, and the whole society also significantly influence it. Therefore, the task of education is to develop in youth a kind of instinct for self-preservation, able to protect against evil suggesty.

The second element of upbringing is science, which is given to children by relatives and teachers and to which the child reaches himself through reading. It should have a good impact on the person, when, first, mind and heart of a human are developed together with knowledge and, secondly, when it gives a true and comprehensive knowledge. Otherwise, science can harm a person. "We had the opportunity", A. Sheptytsky writes, "to learn about the influence of the materialist school. We have seen how it is able to product really good experts, but we have also seen how the materialistic worldview harms the human mind, taking away from it almost entirely the ability of abstract thinking, that is, taking away the ideas and the power of ideological thinking",231.

Moreover, science, including Christian Science, can fulfill its educational function only when it is appropriately exalted, when it arouses interest, and its truths are connected with the practice of life, because even "faith without acts is dead".

The third factor in upbringing is the Christian atmosphere. It includes, first, Christian relations in the family, that is, mutual love, respect, following

${ }^{230}$ Ibid. C. 377.

${ }^{231}$ Шептицький Андрей. Листи-послання (1939-1944). Львів, 1991. С. 234. 
of other Christian virtues in life. Secondly, it includes the Christian worldview, following the faithful, not false ideals. When parents consider "the highest and the only good a material well-being, a well-paid job for children, regardless of sphere of work and regardless of service to the Church and motherland, then such ideals will slowly instill in the souls of children. Then icons and books will not help much; they will only be the cover of gross materialism"232. Therefore, wise parents must consciously cultivate in their children the highest ideals of Christian righteousness and holiness, the sacrificial service to God and the Church, the sincere and sacrificial love to the homeland. Third, the Christian community and the activities of pastors play an important role in shaping the Christian atmosphere. The main requirement here is not to be satisfied with the clear presentation of the truth, but to pave the way for the Word of God to human hearts, to influence the will and feelings. Because, as A. Sheptytsky notes with a humor, for the Slavs the belief of the mind has little meaning in comparison with what can be called "to get into the heart",233.

A. Sheptytsky considers that the basics, the most important principles of education are next: a) preservation of innocence in youth; b) fostering humility; c) fostering courage; d) fostering prayer.

The sence of innocence is to abstain from sin, of moral evil, the indignity of God, and it is the center of all the work of Christian education.

The essence of humility is the elimination of the most important obstacle to God's Grace, which is the pride and disordered non-Christian desire for self-elevation. In applying to life, humility is the virtue that shows a person all its shortcomings and needs.

Courage is a major virtue not only in the Christian but also in the secular system of upbringing. Both these systems of education can form heroes, that is, people who are capable with their extraordinary actions "to be carried beyond their own nature and to unite some divine power in themselves" ${ }^{234}$. The difference between them is in the impetus to courage: in Christianity, such a motivating factor is the love to God, embodied in the love of one's neighbor.

Fostering prayer means building a system of Christian upbringing in which prayer and adherence to the Holy Mysteries are not the acts of compulsion but they are voluntary acts, an indispensable element of one's spiritual life.

\footnotetext{
${ }^{232}$ Шептицький Андрей. Листи-послання (1939-1944). Льввів, 1991. С. 236.

${ }^{233}$ Ibid. C. 238.

${ }^{234}$ Ibid. C. 247.
} 
An important component of Christian education, according to A. Sheptytsky, is the formation in youth of the correct concepts of the Church and the doctrine of the Gospel. Love for the Church should be based on clear concepts of Church unity and a deep faith that there is no salvation outside the Universal Church. At the same time, youth must be nurtured in a spirit of love for the not united Orthodox, an awareness of the necessity and ways of bringing and uniting the Churches, and the church unity should be seen as an integral and dominant element of patriotic education, the formation of national unity. Only under such a condition, according to Sheptytsky, one can get rid of the false idea of patriotic upbringing as creating hatred against enemies. You can judge, you can hate the wrong concepts, mistakes, but people should always be loved everywhere.

This part of the Christian educational system seems to be the weakest in Andrey Sheptytsky's opinion. "Why do pagans come out of our Christian schools?" he asks. "Why do not Christians sometimes come out of the priestly families but worshipers of Perun, or some other god, or just people for whom "God's a stomach"?.. This is a terrible question, it is a problem that the Clergy needs to think well about. This is almost the same or exactly the same problem as if Ukrainians, who are coming out of Ukrainian families and schools, were enemies of Ukrainianness! "Could a school, or system, or family which bring up the traitors, enemies of the people, be genuinely considered a Ukrainian school, or a system, a family?!"235.

According to A. Sheptytsky, the reason for the failures and sores of our ecclesiastical and national life is that Christianity, the doctrine of the Gospel, is often treated and communicated too utilitarianly, as the doctrine of the true system of earthly life. The gospel is indeed such, but it is still the doctrine of holiness, the way to heaven. "Life, according to the doctrine of the Gospel, is the supernatural life of God's grace, the life of God's love and the sacrifice for God, or simply: the life in which one looks for holiness and moves to it" ${ }^{\prime 236}$.

It should be noted that when analyzing the problems of education, Metropolitan Andrey in his pastoral messages to the clergy and the believers constantly draws attention not only to the question of what virtues should be cultivated, but also to what Christian education should be opposed to. Destruction of people, physical and spiritual, drunkenness and the system of limitation of the posterity, neglect of labor - "are such social and folk ailments that simply lead people to the destruction. And while they are bringing it to a complete ruin, they provoke such a degeneration, such a

${ }^{235}$ Шептицький Андрей. Листи-послання (1939-1944). Львів, 1991. С. 252.

${ }^{236}$ Шептицький Андрей. Листи-послання (1939-1944). Львів, 1991. С. 254. 
decline of every culture, such a ruin of physical health and all Christian righteousness, that those objects cannot be touched without a terrible fear about our future" 237 .

Thus, in his cultural, educational and pedagogical activities, Metropolitan Andrey Sheptytsky relied on a well-reasoned, logically argumented, sophisticated theological-philosophical system of beliefs that he tried to bring into life. His writings include, in addition to the above, such deeply scientific philosophical-theological and ascetic works as "God's Wisdom", from which only the third section (1936) is published, then a great work (in three volumes) on Metropolitan V. Rutsky, which is still a manuscript, and also translation of the works of St. Basil the Great, etc.

Metropolitan also had a great interest in church and general history. In 1921 in Rome, he founded the Ukrainian Historical and Church Mission, whose purpose was to search, register and copy the previously unknown documents from the Vatican and Roman archives that are directly related to Ukraine. Sheptytsky himself found more than 6,000 valuable documents from the times earlier than 17th century, including those, which were published after his death in the original languages in ten large-format volumes (9 books). A. Sheptytsky has been engaged in scientific work throughout his life. Even at the end of his life, despite the paralysis of his right hand and both feet, which he did not possess for the last 14 years of his life, despite the difficult duties of the Metropolitan, he spent all his free time in the personal library, which, incidentally, was one of the best not only in the Western Ukraine. However, despite its importance for the church and for him personally, his cultural, educational, pedagogical, scientific, social and political activitiy was not the main one. First of all, Andrey Sheptytsky was Metropolitan, for all 44 years, and even if in his actions he went beyond purely church affairs, there he also acted as the Kniaz of the Church.

${ }^{237}$ Ibid. C. 396; 14-15; 25-28; 222-231. 